\title{
SOME PHYSICAL AND MECHANICAL PROPERTIES OF SODOM APPLE (Calotropis Procera)
}

Ghanem, T. H.* Nagy, K. S.** Badr, M. M.*** and Darwish, E. A.****

\section{ABSTRACT}

The aim of this research is to study some physical and mechanical properties of Sodom apple (Calitropis procera), to help in designing and developing of specific machine and their operations such as harvesting, cleaning, grading and separation.

The main results in this study can be summarized as follows:

Physical properties of Sodom apple seeds fruits: length $=5.19-6.98 \mathrm{~mm}$, width $=3.16-5.87 \mathrm{~mm}$, thickness $=0.38-0.70 \mathrm{~mm}$, geometric diameter $=1.99-2.82 \mathrm{~mm}$, arithmetic diameter $=3.21-3.77 \mathrm{~mm}$, flat surface area $=7.07-9.84 \mathrm{~mm}^{2}$, transverse surface area $=2.89$ $5.06 \mathrm{~mm}^{2}$, volume $4.12-11.68 \mathrm{~mm}^{3}$, mass of 1000 seeds $=5.84-7.05 \mathrm{~g}$, bulk density $=200.97 \mathrm{~kg} / \mathrm{m}^{3}$, real density $=929.50 \mathrm{~kg} / \mathrm{m}^{3}$ and moisture content $=8.43 \%$ w.b.

Mechanical properties: The lowest values of repose angle for seeds were on fiber glass followed by galvanized sheet, plywood, rubber and the highest on perforated sheet $\left(20.86^{\circ}, 34.81^{\circ}, 48.86^{\circ}, 55.63^{\circ}\right.$ and $62.46^{\circ}$ ) respectively. Tensile strength between fibers and seeds was 0.0986N.

\section{INTRODUCTION}

0 odom apple plant belongs to Asclepiadaceae family, this family includes about 350 genera and about 1700 species, all kinds of this species contain latex which is milky juice. The habitat of this species is tropical areas in Africa. Sodom apple plant is chive shrub, middle size and about 3-5 $\mathrm{m}$ in height. The plant grows in desert sandy areas as Sinai, Cairo- Ismailia way and other sporadic desert places in Egypt.

\footnotetext{
* Prof. of Ag. Eng., Fac. of Ag. Eng, Al-Azhar Univ., Cairo. ** Prof. of process Eng., Food Tech. Res. Inst., Ag. Res. Center. ***Lecturer of Ag. Products Porocess Eng. Dept., Fac. of Ag. Eng., Al-Azhar Univ., Cairo, Egypt.

****Assist. Lecturer., of Ag. Eng., Fac. of Ag. Eng., Al-Azhar Univ.
} 
Also it is found in Saudi Arabia, United Arab Emerates and all of tropical countries and desert areas like India, Pakistan, and Afghanistan. Often it is found in sandy areas rarely in coastal dunes. The most plentiful areas of this plant are dry places with few rains. If it rained in areas where it grows, or irrigated frequently, the plant will die, sodom apple plant was used hundred years ago in medicine. This was reported in ancient Egyptian medicine in "Hirest paper" this paper was described for diseased blood vessels contained (sodom apple plant, wheat flour and dom) all are placed in an affected area to heal. Also it was used in ancient Arabic medicine, sodom apple plant thrives at the beginning of summer with violet flowers its fruit appears after this taking the shape and size of mango fruit, inside the fruit fibers like cotton appears, when cut the seeds will appear (FAO, 1986).

Sodom apple is a member of the Asclepiadaceae, woody, broad leaf evergreen coarse shrub, 3-5 m tall as in Fig. (1). All parts of the plant exude white latex when cut or broken. Leaves are opposite, simple, subsessile, stipule absent; blade oblong-obovate to broadly bovate as in Fig. (2). Fruit, a simple, fleshy, inflated, subglobose to obliquely ovoid follicle up to $10 \mathrm{~cm}$ or more in diameter as in Fig. (3). Seeds numerous, flat obovate $(6 \times 5) \mathrm{mm}$, with silky white pappus $3 \mathrm{~cm}$ or more long as in Fig. (4) (Grace, 2006).

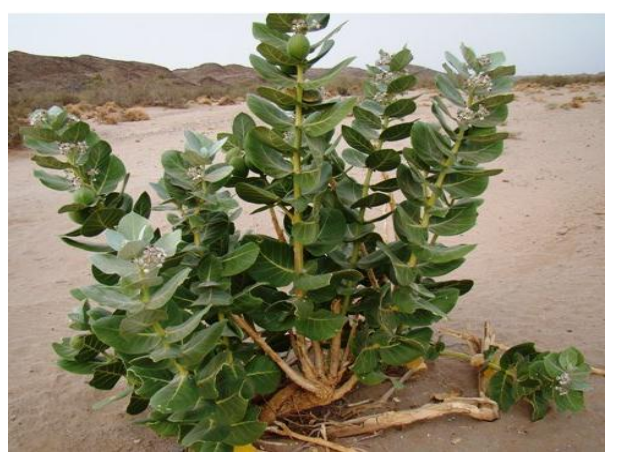

Fig. (1): The parts of the sodom apple plant.

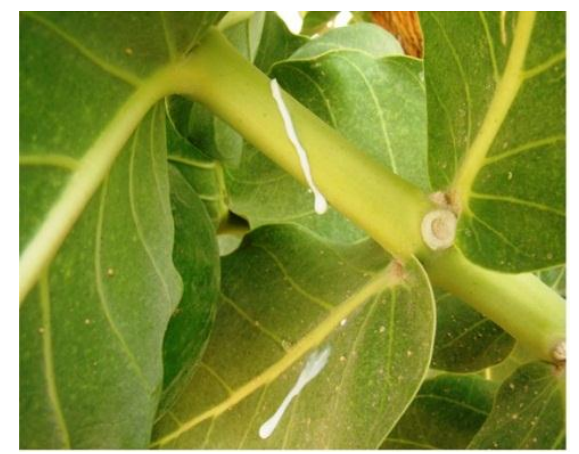

Fig. (2): Leaves and latex of the sodom apple plant. 


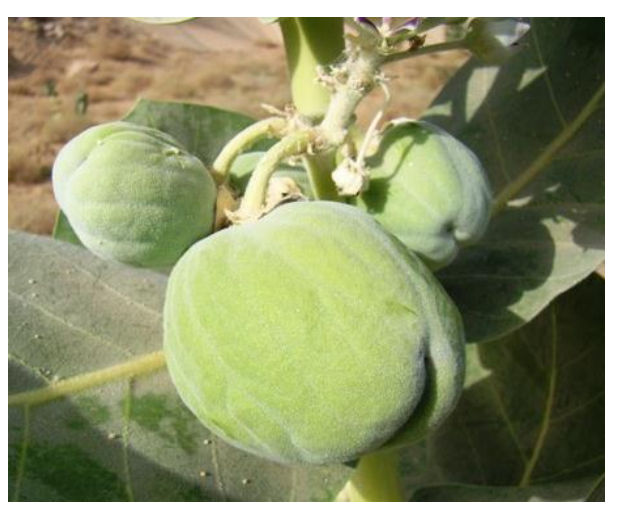

Fig. (3): Sodom apple fruits.

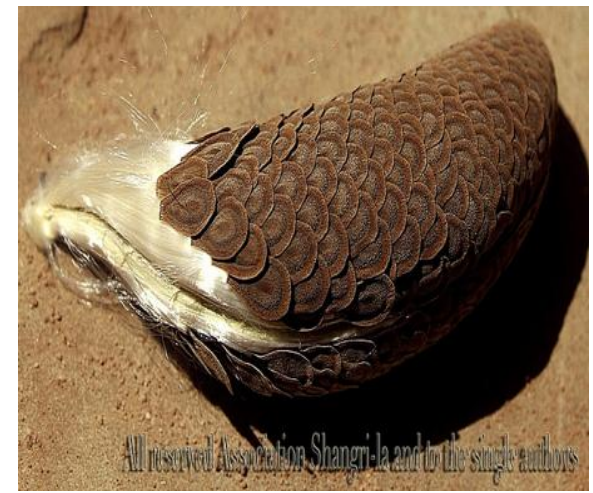

Fig. (4): The contents of the sodom apple fruit.

Barbosa et al. (2014) reported that the seed oil content of sodom apple plant ranged from 19.7 to $24.0 \%$. Five main fatty acids were identified, with a predominance of unsaturated linoleic and oleic acids (approximately 70\%). The oil profile of sodom apple plant presents interesting features that highlight its potential as a future alternative for the biodiesel market, especially in semi-arid regions.

Abbas (2010) reported that natural sodom apple plant fibers were collected the fabrics of the fibers were separated from the seeds by manual way and stored in paper bags to reserve it. The fabrics were tested and compared with another material to know their specifications to help in using them in the textiles field. She concluded that sodom apple fibers could be spun with other natural and man made fibers, and produce yarns which could be blended with cotton (65\% sodom apple and 35\% cotton), this blended yarn could be weaved.

Mohsenin (1986) mentioned that the physical properties of material such as shape, size, volume, and surface area are important in many problems associated with design or development of specific machine, analysis of the behavior of the product in handling of the material, stress distribution in the material under load, electrostatic separation of grain and light reflectance. One of the important design parameters in conveying of solid materials by air or water in the assumption for the shape of the materials. Accurate estimates of the frontal area and the related diameters are essential for the determination of terminal velocity, drag coefficient and Reynold number. 
Kaleem et al. (1993) reported that the angle of repose is very important in determining the inclination angle of the machine hopper tank.

Soliman (1994) studied that the effect of moisture content on angle of repose of paddy rice. He mentioned that the dynamic angle of repose is one of the mechanical properties needed for the design of agricultural material handling systems and storage.

\section{MATERIALS AND METHODS}

\section{- Raw Materials:}

Experiments was carried out on a new raw material (wild sodom apple plant) which was collected from sporadic areas (Mokkatam, MisrIsmailia Desert Road, Nasr city) in the summer months before the fruits bloom and the seeds spread in the air carried by fibers. The raw material (sodom apple) is collected and stored in paper bags to reserve it until the experimental work is started.

\section{-Measuring instruments:}

\section{- Digital caliper:}

A digital caliper (accuracy of $0.01 \mathrm{~mm}$ ) made in China, was used for measuring the seed dimensions.

\section{-Electrical balance:}

Weight of samples were measured by a Sartorius electrical balance made in Japan, (HR- 200, max $210 \mathrm{~g}$ ) having accuracy of (0.0001 g).

\section{-Electric oven:}

The moisture content of sodom apple was evaluated by oven dried (VENTICELL55 type, 230V, 50/60 Hz, 1250W, 250 ${ }^{\circ} \mathrm{C}$ Max. temperature).

\section{- The friction angle:}

The friction angle was measured by an instrument fabricated in the workshop of Agricultural Engineering Faculty Al-Azhar University, Nasr city, Cairo. various materials plywood, perforated sheet, galvanized sheet, fiber glass and rubber were installed on the changeable plane to study the effect of these materials on the friction angle.

\section{-Toluene $\left(\mathrm{C}_{7} \mathrm{H}_{8}\right)$ :}

Toluene was used to estimate the real volume of seeds by using the liquid displacement method because it has the advantage of little absorption by 
seeds and little surface tension which are valuable for estimating the true density with high accuracy.

\section{-Rigidity force:}

A digital force gauge of accuracy $0.2 \%$ was used for measuring the rigidity force. Maximum reading of $2200 \mathrm{~g}$, so a lever construction was used for minimizing the reaction force increasing the precision and amplifying the force reading, due to lever weight.

\section{- Calculations:}

- Seeds dimension:

Characteristic dimensions as length, width, and thickness $(\mathrm{mm})$ were measured by using digital dial caliper. These physical characteristics can be utilized effectively in design and development of the separating prototype and affecting their ginning operations and in analyzing the behavior of product in handling, sieving and separating processes. The following relations can be used for calculating the geometric diameter " $\mathrm{D}_{\mathrm{g}}$ " (mm) arithmetic diameter " $\mathrm{D}_{\mathrm{a}}$ " (mm) and volume "V" $\left(\mathrm{mm}^{3}\right)$ of an individual seed according to (Matthews, 1991) as:

$$
\begin{aligned}
& D_{g}=(L . W . T)^{\frac{1}{3}} \mathrm{~mm} \\
& D_{a}=\left(\frac{L+W+T}{3}\right) \mathrm{mm} \\
& V=\frac{\pi}{6}(L . W . T) \mathrm{mm}^{3}
\end{aligned}
$$

where: $\boldsymbol{L}$ : Length, (mm), $\boldsymbol{W}$ : Width, (mm) and $\boldsymbol{T}$ : Thickness, (mm).

\section{-Seed surface area:}

The surface area of seeds is very important characteristic in determining both volumetric and gravimetric heat transfer coefficients and in analyzing heat and moisture transfer during drying processes, and it is also useful for describing the rehydration process. The following relations were used for calculating the transverse surface area $\left(A_{t}\right)$, and the flat surface area $\left(\mathrm{A}_{\mathrm{f}}\right)$ in $\left(\mathrm{mm}^{2}\right)$, according to (Matthews, 1991) as:

$$
A_{t}=\frac{\pi}{4}(W . T) \quad \mathrm{mm}^{2}
$$




$$
A_{f}=\frac{\pi}{4}(L . W) \mathrm{mm}^{2}
$$

\section{- Bulk density ( $\rho d)$ :}

The bulk density was calculated for the seeds by dividing the mass of quantity of seeds on its volume, which was measured by using constant volume cylinder (Matthews 1991) as:

$$
\rho_{d}=\frac{W_{b}}{V_{b}}
$$

Where: $\rho_{d}$ : Bulk density of seeds, $\left(\mathrm{kg} / \mathrm{m}^{3}\right)$;

$$
\begin{aligned}
& W_{b}: \text { Mass of the quantity of seeds, }(\mathrm{kg}) \text {; and } \\
& V_{b}: \text { Volume of the quantity of seeds, }\left(\mathrm{m}^{3}\right) \text {. }
\end{aligned}
$$

\section{- Moisture content:}

The moisture content of seeds was determined using oven method for all experiments according to the procedure described in the standard methods (ASAE, 1994); oven dried at $105^{\circ} \mathrm{C}$ for 24 hours, moisture content was calculated on wet and dry basis as follows:

Moisture content "M.C" w. b, (\%):

$$
\text { M.C }=\frac{W_{m}}{W_{m}+W_{d}} \times 100
$$

Moisture content " $M$ " d. b, (\%):

$$
M=\frac{W_{m}}{W_{d}} \times 100
$$

Where: $W_{m}$ : Mass of moisture in sample, $(\mathrm{g})$; and

$W_{d}$ : Mass of bone-dry material, $(\mathrm{g})$.

\section{- Friction coefficient ( $\Psi)$ :}

Friction coefficient was measured between (seeds, fibers and raw material) and fiber glass, rubber, perforated steel, galvanized metal and plywood surfaces. 


\section{$\Psi$ Friction coefficient $=\tan \beta$}

Were: $\beta$ : Friction angle.

\section{-Repose angle of seeds $(\infty)$ :}

It is the angle between the horizontal base and the inclined side of the formed cone due to free fall of seeds sample. The horizontal base of the cone $(\mathrm{x})$ and its height $(\mathrm{L})$ were measured by a ruler and the repose angle can be calculated as follows:

$$
\tan \infty=\frac{L}{0.5 X}
$$

\section{-Tensile strength between fibers and seeds:}

A lever setup by Ghanem and Zaalouk (2003) was used for amplifying the force measured by the digital force gauge; its maximum reading of $2200 \mathrm{~g}$ to $123 \mathrm{~N}$ in their study for measuring the rigidity of Cowpea seeds. Whereas in this study of sodom apple the tensile strength between seed and fiber requires minimizing the reaction force and increasing its precision. To achieve this goal, a very light aluminum sheet is used for lever setup, as shown in Fig. (5). When the acting force is zero $\left(\mathrm{F}_{0}\right)$ the weight exerted by the lever caused a reaction $\left(\mathrm{R}_{0}\right)$ on zero load, this reaction was measured by the gauge. The $\mathrm{R}_{0}$ reaction can be determined as follows:

$$
F_{0} L_{1}=R_{0} L_{2} \quad \text { and } \quad R_{0}=\frac{F_{0} L_{1}}{L_{2}}
$$

When the gauge exerted a force on the short arm end $(\mathrm{F})$, the total force $F_{m}=\left(F_{0}+F\right)$ on the short arm end $\left(L_{1}\right)$ so, the net reaction exerted between sodom apple fiber and seed can be determined as follows:

$$
R=C\left[\left(\frac{L_{1}}{L_{2}} \times\left(F+F_{0}\right)\right)-R_{0}\right]
$$

$$
\text { and } \quad R=0.01\left[\left(0.58 F_{m}\right)-5.83\right]
$$

Where: $\boldsymbol{R}$ : Reaction required for separating fiber from seed, (N);

$\boldsymbol{F}_{\boldsymbol{m}}$ : Force exerted by the gauge sensor, $(\mathrm{g})$; 
$\boldsymbol{F}_{\boldsymbol{0}}$ : Force exerted by the gauge sensor at zero load, (10 g);

$\boldsymbol{R}_{\boldsymbol{0}}$ : Reaction caused by the lever weight at zero force, $(5.83 \mathrm{~g}) ; \boldsymbol{L}_{\boldsymbol{l}}$ :

Short arm of the lever, $0.35 \mathrm{~m}$;

$\boldsymbol{L}_{2:}$ Long arm of the lever, $0.60 \mathrm{~m}$; and

$C$ : Constant to convert the total load in N.

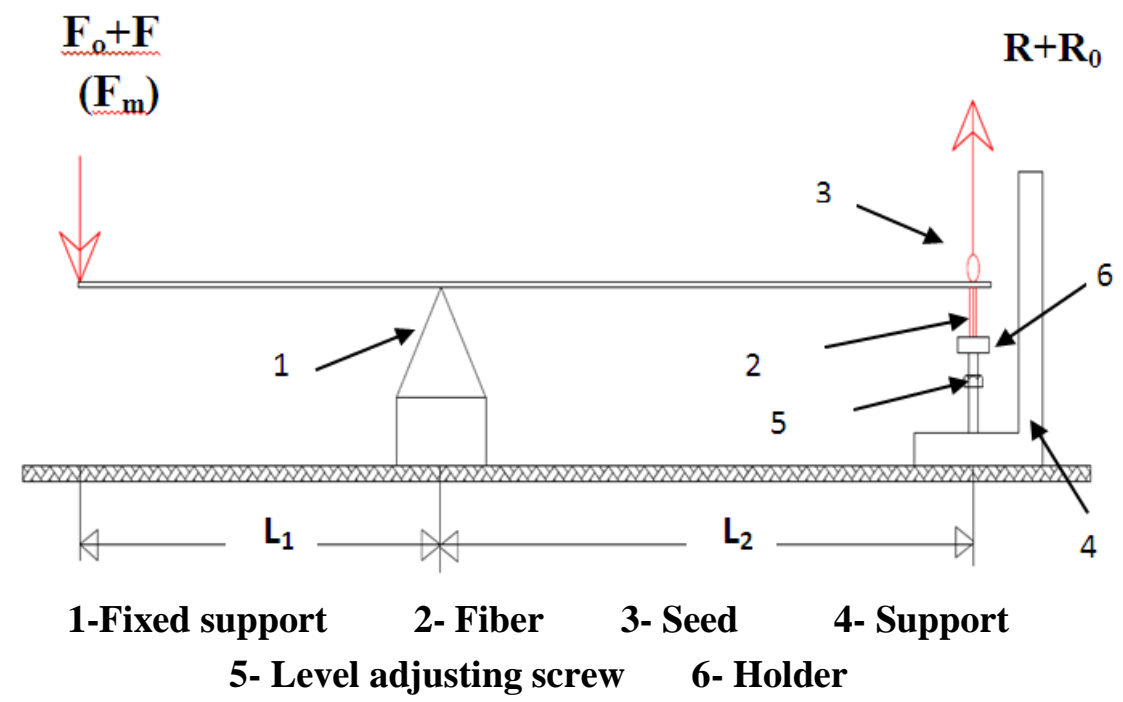

Fig. (5): Lever setup used for amplifying the force measured by the digital force gauge.

\section{RESULTS AND DISCUSSION}

- Evaluation of some physical and mechanical properties of Sodom apple:

Due to the lack of information about physical and mechanical properties related to separation of sodom apple and to set a database for other characteristics related to handling, drying, cleaning, storage and other future processing. Some physical and mechanical characteristics of raw material, seeds and fiber were evaluated in the Faculty of Agricultural Engineering, Al-Azhar University, Nasr city, Cairo, in 2013 - 2014.

Sodom apple raw material (seeds and their fibers) is too light that it can fly in stagnant air or we can say that it has very low density. Although these characteristics are essential for plant spreading and type preservation, they form substantial problems in plant drying, ginning and other future processing. 


\section{- physical properties of sodom apple seeds:}

Tables (1) indicated that the seeds length, width, thickness, geometric diameter, arithmetic diameter, flat surface area, transverse surface area and volume ranges of sample were 5.19-6.98 (average $6.27 \mathrm{~mm}$ ), 3.165.87 (average $3.87 \mathrm{~mm}$ ), 0.38-0.70 (average $0.58 \mathrm{~mm}$ ) 1.99-2.82 (average $2.40 \mathrm{~mm}$ ), 3.21-3.77 (average $3.57 \mathrm{~mm}$ ), 7.07 - 9.84 (average $7.96 \mathrm{~mm}^{2}$ ), 2.89-5.06 (average $3.49 \mathrm{~mm}^{2}$ ) and 4.12-11.68 (average $7.33 \mathrm{~mm}^{3}$ ) respectively.

Table (1): Physical properties of sodom apple seeds.

\begin{tabular}{|c|c|c|c|c|c|c|}
\hline \multicolumn{2}{|c|}{ Physical properties of seeds } & Max. & Min. & Ave. & S.D & C.V \% \\
\hline \multirow{3}{*}{ 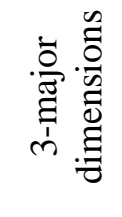 } & Length (mm) & 6.98 & 5.19 & 6.27 & 0.45 & 0.07 \\
\hline & Width (mm) & 5.87 & 3.16 & 3.87 & 0.36 & 0.09 \\
\hline & Thickness (mm) & 0.70 & 0.38 & 0.58 & 0.08 & 0.14 \\
\hline \multicolumn{2}{|c|}{ Geometric diameter $(\mathrm{mm})$} & 2.82 & 1.99 & 2.40 & 0.15 & 0.06 \\
\hline \multicolumn{2}{|c|}{ Arithmetic diameter (mm) } & 3.77 & 3.21 & 3.57 & 0.19 & 0.05 \\
\hline \multicolumn{2}{|c|}{ Flat surface area $\left(\mathrm{mm}^{2}\right)$} & 9.84 & 7.07 & 7.96 & 0.43 & 0.05 \\
\hline \multicolumn{2}{|c|}{ Transverse surface area $\left(\mathrm{mm}^{2}\right)$} & 5.06 & 2.89 & 3.49 & 0.29 & 0.08 \\
\hline \multicolumn{2}{|c|}{ Volume $\left(\mathrm{mm}^{3}\right)$} & 11.68 & 4.12 & 7.33 & 1.37 & 0.19 \\
\hline \multicolumn{2}{|c|}{ Mass of 1000-seeds (g) } & 7.05 & 5.84 & 6.26 & \multicolumn{2}{|c|}{---} \\
\hline \multicolumn{2}{|c|}{ Bulk density $\left(\mathrm{kg} / \mathrm{m}^{3}\right)$} & \multicolumn{5}{|c|}{200.97} \\
\hline \multicolumn{2}{|c|}{ Real density $\left(\mathrm{kg} / \mathrm{m}^{3}\right)$} & \multicolumn{5}{|c|}{929.50} \\
\hline \multirow{2}{*}{ 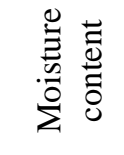 } & $\%$ w.b & 8.43 & 7.61 & 7.92 & \multicolumn{2}{|c|}{--} \\
\hline & $\%$ d.b & 9.20 & 8.23 & 8.61 & \multicolumn{2}{|c|}{--- } \\
\hline
\end{tabular}

- Mechanical properties of sodom apple:

- Friction angles for seeds, fibers and raw material:

Figs. (6), (7) and (8) show the friction angle evaluated for seeds, fibers and raw material respectively on different surfaces including plywood, perforated sheet, galvanized sheet, fiber glass and rubber. 
The lowest values of friction angle for seeds were on fiber glass followed by galvanized sheet, rubber, plywood and the highest on perforated sheet, $\left(24.4^{\circ}, 35.2^{\circ}, 35.8^{\circ}, 42.8^{\circ}\right.$ and $\left.43^{\circ}\right)$ respectively, while the lowest values of friction angle for fibers were on galvanized sheet followed by fiber glass, rubber, perforated sheet and the highest on plywood, $\left(41.6^{\circ}, 43^{\circ}\right.$, $44.8^{\circ}, 51.4^{\circ}$ and $63.8^{\circ}$ ) respectively, it is also clear that the lowest values of friction angle for raw material were on fiber glass followed by galvanized sheet, rubber, perforated sheet and the highest on plywood, $\left(33.4^{\circ}, 38.4^{\circ}, 41^{\circ}, 55.8^{\circ}\right.$ and $\left.56.6^{\circ}\right)$ respectively. This is due to the smoother and more polished surface of galvanized sheet and fiber glass than the other tested surfaces.

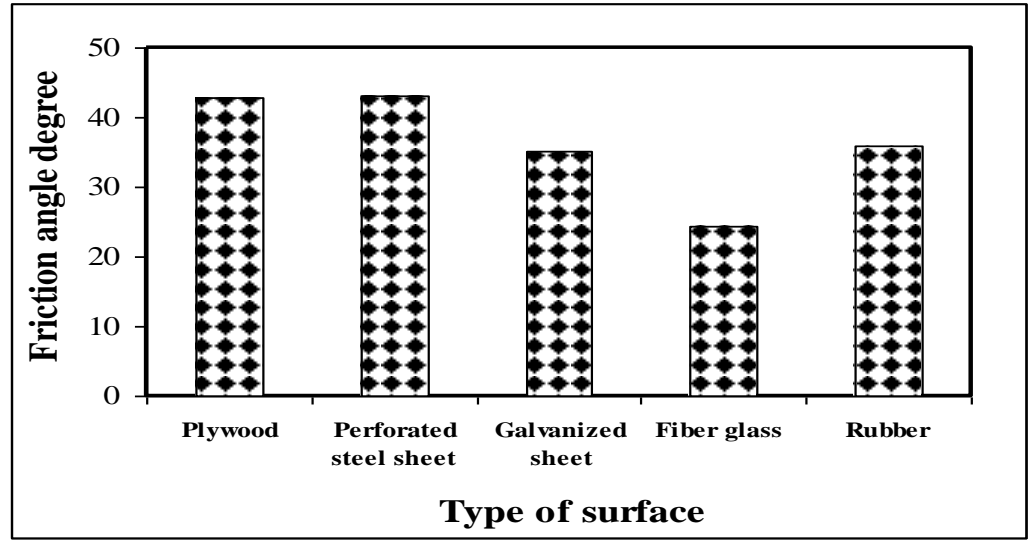

Fig.(6): Friction angle for seeds on different surfaces.

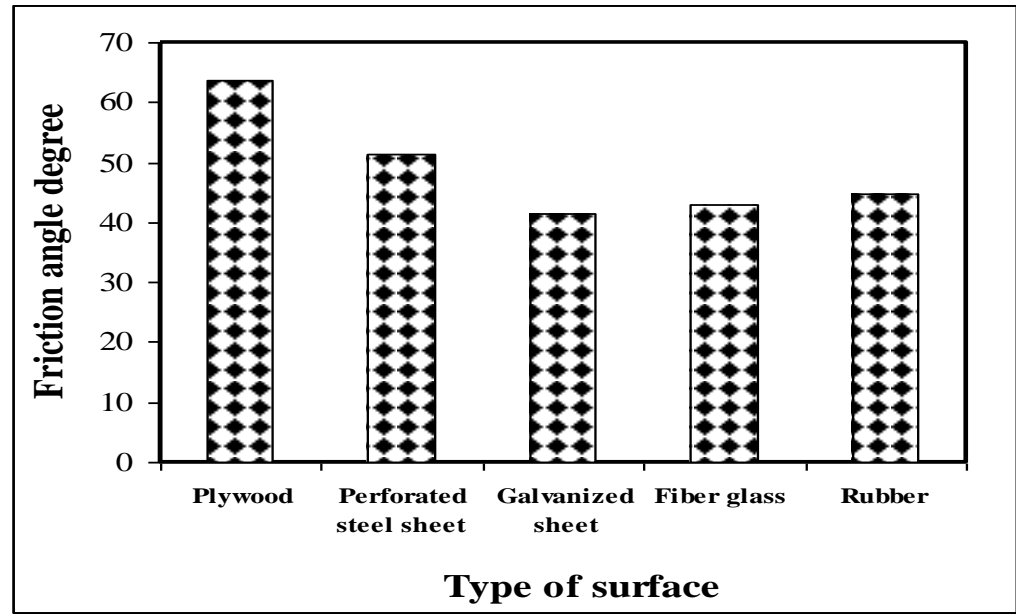

Fig. (7): Friction angle for fibers on different surfaces. 


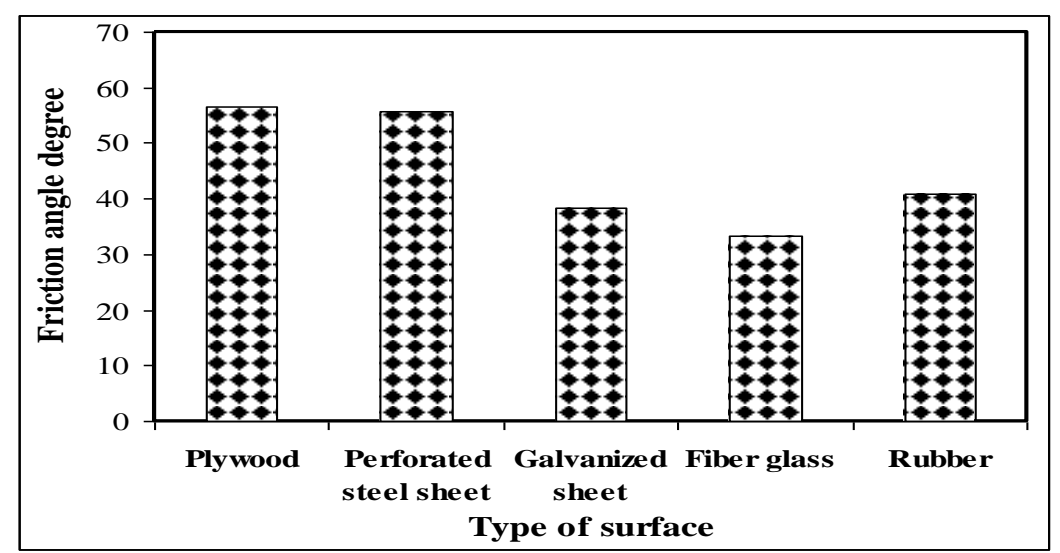

Fig. (8): Friction angle for raw material on different surfaces.

\section{-Angle of repose for seeds:}

Fig. (9) show the angle of repose for seeds on the selected material surface including plywood, perforated sheet, galvanized sheet, fiber glass and rubber.

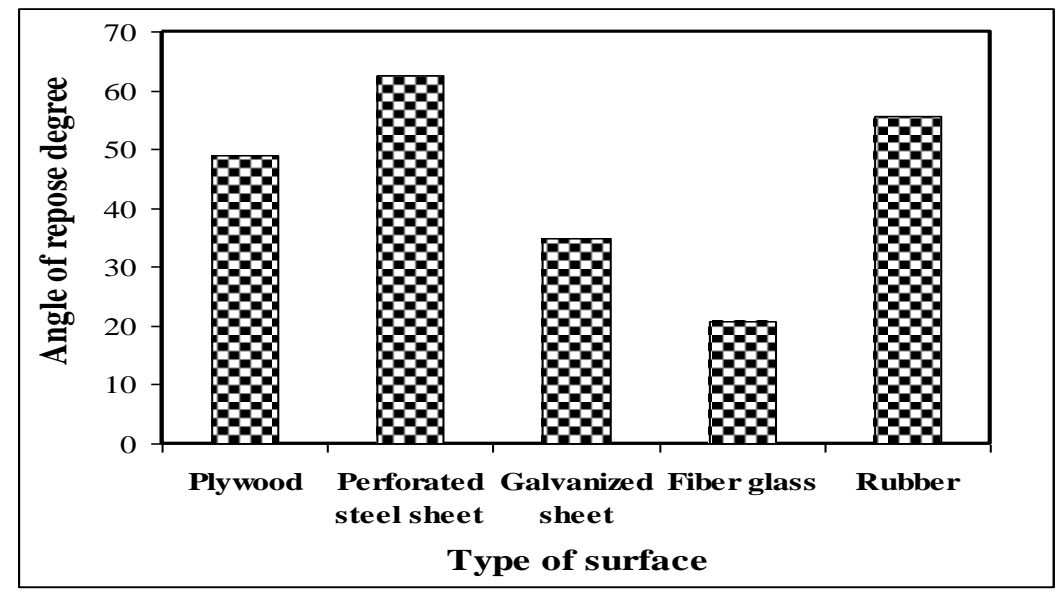

Fig. (9): Angle of repose for seeds on different surfaces.

The lowest values of repose angle for seeds were on fiber glass followed by galvanized sheet, plywood, rubber and the highest on perforated sheet $\left(20.86^{\circ}, 34.81^{\circ}, 48.86^{\circ}, 55.63^{\circ}\right.$ and $\left.62.46^{\circ}\right)$ respectively.

Present data can be utilized in future work for flat belts conveying of seeds. The angle of inclination of the flat belt should be less than repose angle of the selected material.

- Tensile strength between fibers and seeds:

The Tensile strength ranges of samples were 0.076-0.134 $\mathrm{N}$ (average $0.0986 \mathrm{~N})$. 


\section{CONCLUSION}

Sodom apple is a valuable source of fiber, which can be used in textiles to produce a strong natural fabrics silk with high quality. And the seeds of this plant can be used for medicinal purposes to treat some diseases, it is also a good source of oils $(17-30 \%)$ it is possible to intervene in some industries to extract oils and it is a promising source for biofuels. And then the main objective of the present work is to study some physical and mechanical properties of Sodom apple to set a database for future studies related this plant.

\section{The results can be summarized as follows:}

1. Some physical properties of averaged values of Sodom apple seeds were studied as: length, width, thickness, volume, geometric diameter, arithmetic diameter, bulk density, real density, transverse surface area, flat surface area, mass of 1000- seeds and moisture content wet and dry basis were $6.27 \mathrm{~mm}, 3.87 \mathrm{~mm}, 0.58 \mathrm{~mm}, 7.33 \mathrm{~mm}^{3}, 2.40 \mathrm{~mm}, 3.57 \mathrm{~mm}$, $200.97 \mathrm{~kg} / \mathrm{m}^{3}, 929.5 \mathrm{~kg} / \mathrm{m}^{3}, 3.49 \mathrm{~mm}^{2}, 7.96 \mathrm{~mm}^{2}, 6.26 \mathrm{~g}$ and $7.92 \%$ and $8.61 \%$ respectively.

2. Some mechanical properties as friction angle and angle of repose were studied.

- The lowest values of friction angle for seeds were on fiber glass followed by galvanized sheet, rubber, plywood and the highest on perforated sheet, $\left(24.4^{\circ}, 35.2^{\circ}, 35.8^{\circ}, 42.8^{\circ}\right.$ and $\left.43^{\circ}\right)$ respectively

- The lowest values of repose angle for seeds were on fiber glass followed by galvanized sheet, plywood, rubber and the highest on perforated sheet $\left(20.86^{\circ}, 34.81^{\circ}, 48.86^{\circ}, 55.63^{\circ}\right.$ and $\left.62.46^{\circ}\right)$ respectively.

- Tensile strength between fibers and seeds was also studied and found to be average $0.0986 \mathrm{~N}$.

\section{REFERENCES}

Abbas, A. A., (2010). Study of the possibility of produce textile by sodom apple fibers. Ph.D. Thesis. Textile, Dep., Fac. of Applied Arts, Helwan U.:4-21.

ASAE, (1994). ASAE standards. American Society of Agricultural Engineers. St. Joseph USA.

Barbosa, M. O.; J. S De-almeida-Cortez; A. F. De-Oliveira and S. I. Da-Silva, (2014). Seed oil content and fatty acid Composition from 
Different Populations of Calotropis procera (Aiton). Journal of the American Oil Chemists' Society 91:1433-1441.

FAO, (1986). Some medicinal plants of Africa and Latin America. FAO Forestry Paper. 67. Rome, Italy.

Ghanem, T. H. and A. K. Zaalouk, (2003). Some physical and mechanical properties of Cowpea seeds. Misr J. Ag. Eng., 20(2): 363-379.

Grace, B. S., (2006). The biology of Australian weeds 45. Calotropis procera (Aiton) W.T.Aiton. Plant Protection Quarterly. 21:152160.

Matthews, J., ( 1991) Progress in Agricultural physics and Engineering. (Hand Book). Chapter (8): 203-227.

Mohsenin, N. N., (1986). Physical Properties of Plant and Animal Materials, Gordon and Breach Sc. Pub., N. Y. p: 734.

Kaleem, F. H.; Z. E. Ismail and G.R. Abd-Hakim, (1993). Factors affecting grain cleaning efficiency. Part1: Grian straw mixture and characteristics, Misr J. Ag. Eng.10(2): 369-382.

Soliman, N. S., (1994). Effect of moisture content on angle of repose of paddy rice and its products. Misr.J. Ag. Eng. 11(1): 163-173.

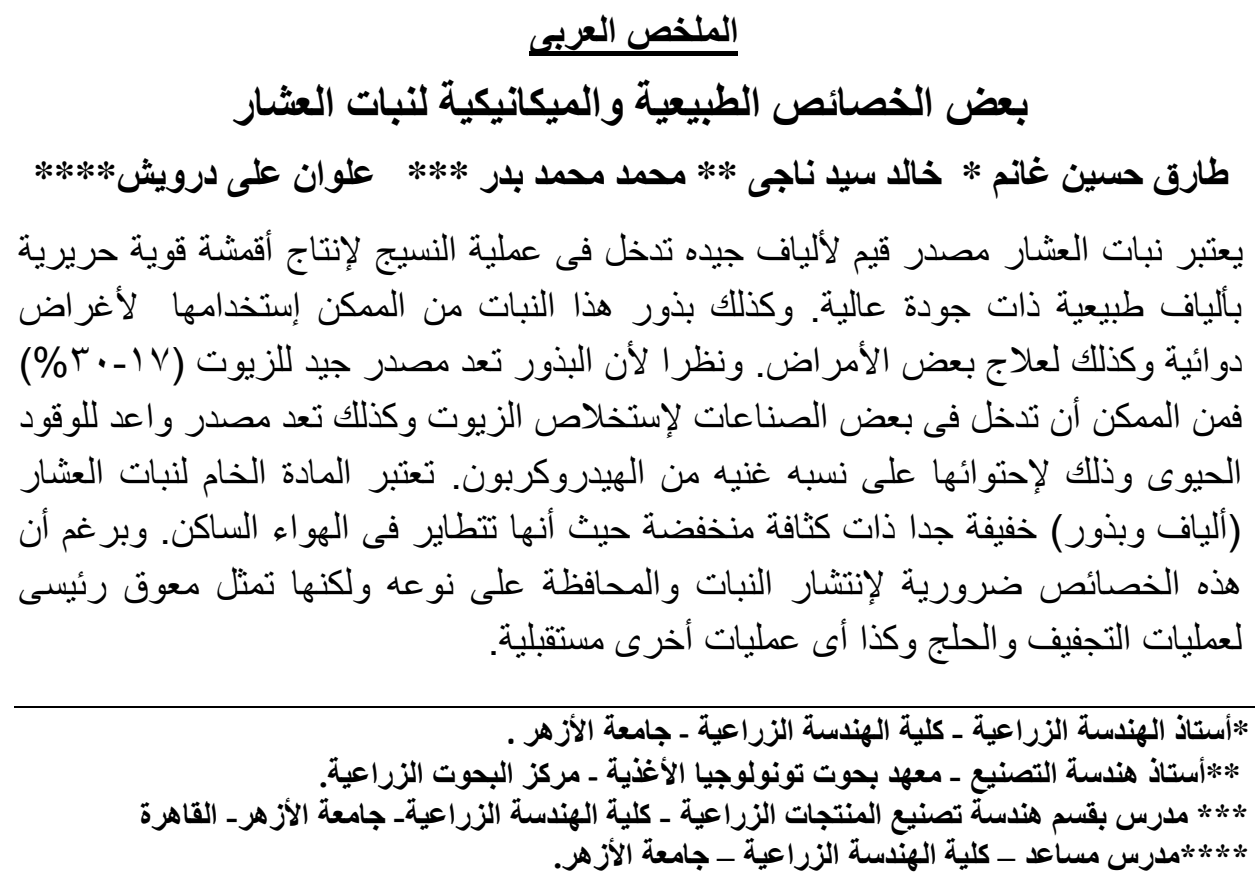


وتهدف هذه الدراسة إلى توفير قاعدة معلومات لبعض الخصائص الطبيعية والميكانيكية لهذا

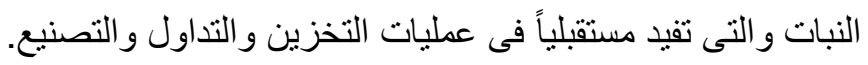
وقد تم تلخيص نتائج هذه الاراسة كالأتى:

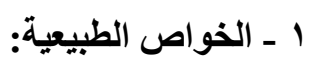
- تم دراسة الخواص الطبيعية الأتية للبذور وأخذ المنوسطات لهذه الخواص للإستفادة منها

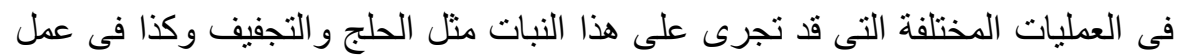

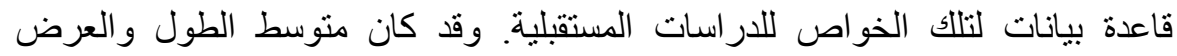
و السمك والحجم و القطر الهندسى و القطر الحسابى والكثافة الظاهرية و الكثافة الحقيقية الكانية

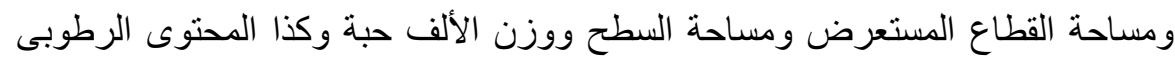

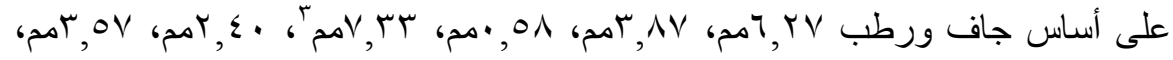

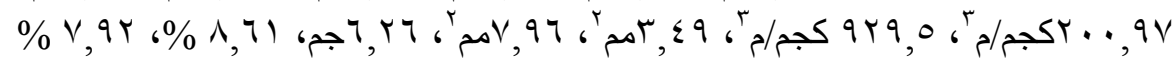

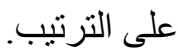

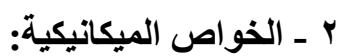
- تم دراسة الخواص الميكانيكية كزاوية الإحتكاك وزاوية التكويم مع الأسطح المختلفة

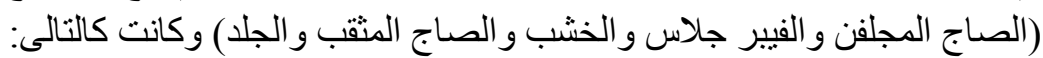

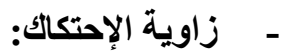

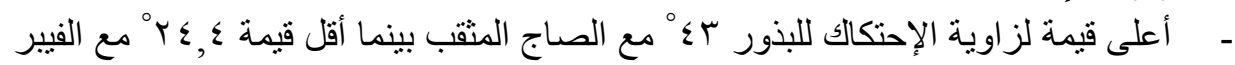

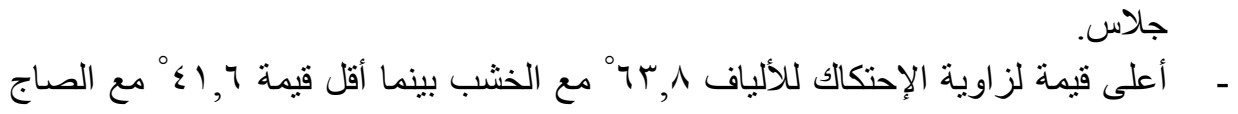

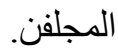

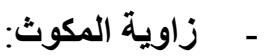

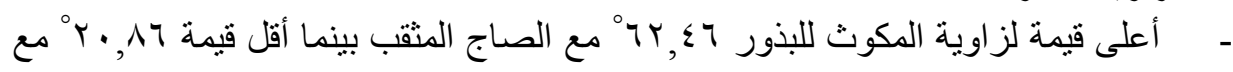

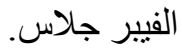

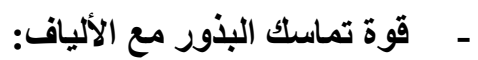
- - كما تم قياس قوة التماسك البذور مع الألياف لعديد من العينات حيث قدر متوسط قوة

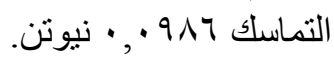

